\title{
1 Prognostic models in obstetrics: available, but far from applicable
}

2

3 C. Emily KLEINROUWELER MD PhD ${ }^{a}$, Fiona M. CHEONG-SEE MRCOG ${ }^{\text {b }}$, Gary S. COLLINS PhD ${ }^{\text {, }}$,

4 Anneke KWEE MD PhD ${ }^{d}$, Shakila THANGARATINAM PhD ${ }^{\text {b,e }}$, Khalid S KHAN MSc MRCOG ${ }^{\text {b,e }}$,

5 Ben Willem J. MOL MD PhD ${ }^{a, 1}$, Eva PAJKRT MD PhD ${ }^{a}$, Karel G.M. MOONS PhD ${ }^{f}$, Ewoud

6 SCHUIT PhD ${ }^{\text {a,f,g }}$

7

8 a Department of Obstetrics and Gynecology, Academic Medical Center, Amsterdam, the Netherlands.

9 b Women's Health Research Unit, Barts and the London School of Medicine and Dentistry, Queen Mary

10 University London, London, United Kingdom.

11 c Centre for Statistics in Medicine, University of Oxford, Oxford, United Kingdom.

$12 \mathrm{~d}$ Department of Obstetrics and Gynecology, University Medical Center Utrecht, Utrecht, the

$13 \quad$ Netherlands

Multidisciplinary Evidence Synthesis Hub (mEsh), Barts and the London School of Medicine and Dentistry, Queen Mary University London, London, United Kingdom. Netherlands. Present address: School of Paediatrics and Reproductive Health, University of Adelaide, Adelaide, SA 5000, Australia.

Conflict of interest statement: The authors report no conflict of interest.

24 Financial support: No funding.

26 Reprints will not be available. 
27 Corresponding author:

28 CE Kleinrouweler

29 Academic Medical Center

30 Department of Obstetrics and Gynecology

31 Meibergdreef 9

321105 AZ Amsterdam

33 Phone: +31205666199

34 Email: c.e.kleinrouweler@amc.uva.nl

35

36 Word count abstract: $254 \underline{302}$

37 Word count main text: $2178 \underline{2802}$ 

models are validated, and their impact on clinical practice is unknown.

40

41 Short title: Prognostic models in obstetrics.

42

43

44

45 


\section{Abstract}

47

48 Healthcare provision is increasingly focused on the prediction of patients' individual risk for

49 developing a particular health outcome in planning further tests and treatments. There has

50 been a steady increase in the development and publication of prognostic models for various

51

52

53

54

55

56

57

58

59

60

61

62 maternal and fetal outcomes in obstetrics. We undertook a systematic review to assess the quality, validity and applicability of prognostic models published in the field of obstetrics. give an overview of the current status of available prognostic models in obstetrics in the context of their potential advantages and the process of developing and validating models. Important aspects to consider when assessing a prognostic model are discussed and recommendations on how to proceed on this within the obstetric domain are given.

We searched MEDLINE (up to July 2012) for articles developing prognostic models in obstetrics. We identified 177 papers that reported the development of 263 prognostic models for 40 different outcomes. The most frequently predicted outcomes were preeclampsia $(n=69)$, preterm delivery $(n=63)$, mode of delivery $(n=22)$, gestational hypertension ( $n=11)$ and small for gestational age infants $(n=10)$. The performance of newer models was generally not better than that of older models predicting the same outcome. The most important measures of predictive accuracy (i.e. a model's discrimination and calibration) were often $(82.9 \%, 218 / 263)$ not both assessed. Very few developed models were validated in data other than the development data $(8.7 \%, 23 / 263)$. Only two thirds of the papers $(62.4 \%, 164 / 263)$ presented the model such that validation in other populations was possible, and the clinical applicability was discussed in only $11.0 \%(29 / 263)$. The impact of developed models on clinical practice was unknown. 
70 We identified a large number of prognostic models in obstetrics, but there is relatively little

71 evidence about their performance, impact and usefulness in clinical practice so that at this

72 point, clinical implementation cannot be recommended. New efforts should be directed towards evaluating the performance and impact of the existing models.

74

75 Keywords: prediction, obstetrics, pregnancy, model

76 
77 Medicine, including obstetrics, is increasingly focused on risk-based or personalized

78 medicine: treatment or preventive interventions as well as elaborate or burdening

79 prognostic tests are administered based on a patients' risk for developing (prognosis) -a

80 certain health outcome (prognosis). ${ }^{1}$ Identification of patients at high risk can be based on a single risk factor, risk indicator or predictor (e.g. a particular patient characteristic,

82 biomarker or test result) or on a combination of multiple predictors. The prevailing thought

83 is that combining predictors into a so-called risk prognostic or decision model allows for

84 better risk assessment and patient selection than single predictors, tests or markers. ${ }^{2}$

85 Two historical examples of prognostic models in obstetrics are the Apgar score to 86 assess the condition of a newborn baby immediately after birth, and the Bishop score to

87 assess cervical ripeness before and during induction of labour. ${ }^{3 ; 4}$ Both models were

88 89 90 corresponding increase in the number of models being applied in practice. The aim of this developed in the 1950-60's, before the introduction of the currently recommended methods for prognostic research, but and-are still widely used in clinical practice presumably because of their relevance and ease of use. Over the years, many prognostic models have been developed and published. ${ }^{1}$ The authors of this opinion paper have signaled a rise in the number of prognostic models being published, including for obstetric outcomes, without the paper is to give a comprehensive overview of the current status of available prognostic models in obstetrics in the context of the potential advantages of prognostic models, the advocated process of developing and validating models, important aspects to consider when assessing a prognostic model, and how we should proceed on this within the obstetric domain.

\section{Why use prognostic models?}


101 The ultimate goal of risk-based management is to allow for timely diagnosis and prognosis

102 and consequently more effective management. Based on patients' risks, interventions can

103 be applied to those that potentially benefit most, thereby improving patient outcomes while

104 saving costs and avoiding unnecessary burden by refraining from treatment for individuals

105 unlikely to benefit from a certain intervention. Here, prognostic models can aid in several

106 ways. They may serve as an alert (e.g., when a woman or newborn needs immediate medical

107 care), be used for individual decision making (e.g., to choose an alternative treatment or

108 refrain from treatment when the chances of success or improvement are low), aid in

109 organizational planning (e.g. availability of staff and the operating theatre when the risk of

110 an operative delivery is high), or allow for individualized counseling of patients (e.g. in the

111 decision of a pregnant woman to opt for external cephalic version). ${ }^{5-8}$ We will first describe

112 the currently available models in obstetrics for potential use.

113

\section{Available prognostic models in obstetrics}

115 As there was no overview of prognostic models available for potential use, we undertook a

116 systematic review of the literature on this topic PRISMA guidelinesStatement.

118 We searched MEDLINE through PubMed on July $1^{\text {st }}, 2012$ without language or publication

119 date restrictions to identify papers reporting on the development of a prognostic model in

120 obstetrics. The search strategy was based on terms related to women, pregnancy and

121 obstetrical topics combined with sensitive and specific methodological filters, ${ }^{9}$ allowing

122 efficient identification of publications on prognostic models (Appendix 1). We defined a

123 prognostic model as a model that could be used to estimate risks for individual patients, or

124 to distinguish groups of patients at different risks, based on three or more predictor 
variables. Papers were excluded if the described model was to be used for diagnosis of a current condition rather than for predicting a future outcome, or the predicted outcome was outside the field of obstetrics, defined as an outcome concerning the pregnant, laboring or post-partum woman immediately after delivery, or the fetus (for example: fetal growth restriction), or the neonate immediately after birth (for example, birthweight). Eligible papers were selected by two reviewers (EK and ES). Titles and abstracts of all papers identified by the search were scrutinized for eligibility. After 300 abstracts were screened in duplicate, which showed good agreement between both reviewers (kappa-statistic $=0.71$, indicating that $98.7 \%$ of papers was scored the same by both reviewers), the remaining were assessed by one reviewer. In case of doubt about eligibility, the paper was discussed with the other reviewer to accomplish a joint decision. Once selected, both reviewers examined the full text papers to see whether they met the inclusion criteria. Disagreements about inclusion at any stage of the selection process were resolved by consensus.

From 10152 citations, a total of 177 papers met inclusion criteria and described the development of one or more obstetric prognostic models (Figure 1). $\cdot^{10-186}$ Overall, we identified 263 models for 40 different outcomes. The oldest paper identified was published in 1976. Since then, the number of available papers and prognostic models increased markedly (Figure 2). These findings are consistent with those reported elsewhere for other clinical areas. ${ }^{187}$ The marked increase in the number of available obstetrical prognostic models indicates that clinicians and researchers are increasingly interested in 'risk-based medicine' or 'personalized medicine' (Figure 3).

Of the 40 different outcomes that were predicted, there were 15 outcomes for which only one model was developed, 14 outcomes for which two or three models were identified, six outcomes for which between four and ten models were available, and five outcomes with 
149 ten or more published models. The five most frequently predicted outcomes were pre150 eclampsia ( $n=69)$, preterm delivery $(n=63)$, mode of delivery $(n=22)$, gestational

151 hypertension $(n=11)$ and small for gestational age neonates $(n=10)$. Among these five 152 outcomes, many more models were developed for predicting pre-eclampsia and preterm 153 delivery than for any other outcome. Both pre-eclampsia and preterm delivery are highly 154 prevalent conditions in obstetrics (up to, and just over, an incidence of $10 \%$, respectively) 155 and are major causes of adverse outcomes. ${ }^{188-190}$ The prevalence and clinical importance of 156 these conditions and the potential benefits of early (preventive) treatment (aspirin for 157 prevention of pre-eclampsia and progestagens, pessary or cerclage for prevention of 158 preterm delivery) and organization of care (antenatal corticosteroids, intra-uterine transfer 159 to centers with neonatal intensive care facilities) may explain the large number of models developed for these outcomes.

161

\section{Important aspects to consider when appraising models}

163 Box 1 describes some of the important concepts in prognostic model studies. Papers describing a prognostic model should report these items that allow for assessment of model performance and applicability, as well as describe a clear definition of the predictors and outcome, details of the population studied, study design (e.g. cohort or case control), sample

167 size and statistical methods including selection of predictors and handling of missing data. ${ }^{191-}$ $168{ }^{193}$ Each model included in the systematic review was thoroughly assessed for methodological development and validation as well as reporting, with the use of a checklist including these items. Appendix 2 gives an overview of all included models and details of their performance, validity and applicability. 
173 and discrimination), presented the model such that it could be used by others, gave

174 guidance for clinical use and whether they were internally or externally validated (or both) is

175 also shown in Table 1. Of the 263 identified models, 57 models (21.7\%) were internally 176 validated and only $23(8.7 \%)$ were externally validated (Figure 2). Details of model

177 performance, either apparent or at internal or external validation, included calibration of 178 only 46 models (17.5\%), details of discrimination for 165 models (62.7\%) and both 179 calibration and discrimination were presented for 45 models (17.1\%). A prognostic formula, 180 rule or score that could be used by others was reported for 164 models (62.4\%) and 181 guidance for clinical use was discussed for 29 (11.0\%). For predicting pre-eclampsia and preterm delivery many models have been developed, but only $7.2 \%(5 / 69)$ and $6.3 \%$ (4/63), respectively, have been externally validated. Overall, model performance was lower at external validation than at apparent or internal validation. High discrimination (area under the receiver operating characteristic curve $(A \cup C)>0.90$ ) either at apparent or internal validation was observed in the development phase of $25 \%$ and $24 \%$ of models for which discrimination was presented, respectively. For preterm delivery, AUCs of models at external validation ranged between

1890.65 and 0.72 . For pre-eclampsia, AUCs were between 0.70 and 0.85 (all models for late pre-

190 eclampsia). For both outcomes we found that recently developed models did not have

191 better performance than already existing models (see also Appendix 2).

193 Why are existing models not yet applicable and not being used?

194 Despite the availability of many models for various outcomes, we are not aware of any 195 (recent) obstetrical models that have found their way into routine practice. The reasons for 
196 this may be multiple: (1) clinicians may be in doubt on whether to rely on probabilities pro-

197 vided by these models (i.e. face validity), ${ }^{6}$ because models may not include well-known

198 predictors of the outcome. Additionally, in obstetrics there tends to be an inverse relation

199 between outcomes of mother and baby, e.g. early delivery to benefit the mother might

200 compromise baby's outcome due to prematurity, so combining models developed on

201 different datasets for maternal and perinatal outcomes may lower face validity. Another

202 related issue, sometimes described as treatment paradox, can corrupt face validity when

203 models are appropriately developed within the same dataset. Predictors of the outcome or

204 interventions that may benefit the mother but at the same time compromise the baby's

205 health or vice versa, leave the clinician in doubt on whether to rely on probabilities provided

206 by these models. (2) Individuals often rely on simple heuristics, i.e. cognitive processes,

207 concious or unconcious, that ignore part of the information, which hampers incorporation of

208 prognostic models into clinical practice ${ }_{\Sigma^{\prime}}^{194}$ (3) Pprognostic models are often too complex for 209 daily use in clinical settings without computer support (although the introduction of

210 computerized patient records will clearly facilitate their application in routine care $)_{\bar{\prime}^{\bar{\gamma}}}^{195}(4)$

211 Ppreventive treatment for the outcome that is predicted may not exists, so clinicians may prefer expectant management instead of using a model-and treat the patient when the disease eventually develops instead of using a model.; (5) Mmany prognostic models have

214 not been validated in other populations, meaning that their generalizability is unclear, ${ }^{196}$ and

$215 \mid(6)$ the reporting and methodological quality may be questionable or unclear, ${ }_{\bar{j}}^{191 ; 192 ; 197-199}$ despite (recommended) methods for development of prognostic models that are well-

217 described and available in commonly used statistical software. ${ }^{1 ; 200}$

219 and its use in practice. ${ }^{6}$ Firstly, one should question whether the implementation of a 
prognostic model with acceptable performance is likely to improve patient care, decision making, patient outcomes, counseling or organization of care. Most authors of the papers

222 identified by our systematic review described in their introduction that the possibility of accurate risk estimation for a variety of conditions would potentially have huge advantages. However, in the discussion it was usually not described how the prognostic model should be used or what was defined as being low or high risk. Secondly, a prognostic model should be developed using a sound methodological approach and its performance combined with ease of application should indicate whether the models warrants further investigation and validation. Interestingly, while reading the full-text papers, we observed that many reported that the addition of biomarkers (such as cervical length, fetal fibronectin, serum protein levels) to characteristics of maternal and obstetric history (age, parity, previous conditions) and routine examinations (body mass index, blood pressure) often improved model discrimination up to an acceptable performance. However, if acceptable performance can be

233 achieved with the use of only 'readily available' variables this could make a model easier

234 (and therefore perhaps more likely) to be used in practice. Thirdly, new or existing models should be externally validated, ideally by independent investigators, and compared to competing models, ${ }^{201}$ and, if necessary, updated. Less than $10 \%$ of the identified models in

237 obstetrics have been externally validated, either in the same paper or by an independent research group. ${ }^{198}$ Additionally, only 164 models (62.4\%) were in-presented in a manner for others to use, meaning that either external validation or clinical use would notbe possible. A fourth step after validation is to investigate whether using the prognostic model actually

241 improves patient care: whether patient outcomes are better when changes in clinical management are made based on, or are supported by, the prognostic information provided by the model. This can be studied, for example, in a randomized trial that compares one or 
more treatment strategies guided by the prognostic model with care as usual (without the model) for relevant patient outcomes. Only one paper in our review discussed the issue of conducting a randomized trial to evaluate the potential clinical benefits of use of the model. ${ }^{39}$ For all others models, impact studies - or evidence of their initiation - were lacking. In this the phase of assessing model impact it should be clear how the model should be used in practice and ideally there should be a recommendation for management of women at risks higher and lower than a certain threshold. Only a tenth of the models in this review discussed guidance for future use.

\section{Comment}

The increasing number of prognostic models for the same outcome along with the dearth of (independent) external validation studies and, more importantly, studies evaluating the clinical impact of using the prognostic model, seems to indicate that researchers in the field of obstetrics fail to appreciate the steps required in the introduction of a new prognostic model. ${ }^{196 ; 202}$ In addition, the realization that almost $40 \%$ of papers failed to present their model in a format that could be used by others (e.g. for external validation) could indicate that developers of prognostic models might not be aware of the necessity of (multiple) external validation. Furthermore, researchers seem not to critically question the consequences of developing another model along existing models for the same outcome. It has even been suggested that the increase in prognostic models can be partly attributed to the simplicity of publishing yet another paper, simply for sake of publication rather than its potential use in clinical practice. ${ }^{203}$ We suggest that before efforts to develop a new model are undertaken, systematic reviews should be carried out to identify and validate existing models with careful consideration to decide whether to develop a new model or update an 
268 existing model. ${ }^{200}$ Afterwards, the most valid, best performing models should be studied in clinical practice in so-called impact studies to investigate its influence on patient outcomes. The usefulness of any prognostic model is predicated on full and transparent 271 reporting of how the model was developed and validated. If key details are not reported, 272 including the actual prognostic model (for which our review finds that $38 \%$ were 273 insufficiently reported), then deciding whether a prognostic model has potential for practice

274 is difficult. ${ }^{193}$ Systematic reviews of prognostic models in other areas of medicine have described inappropriate methodology and reporting, similar to our findings. ${ }^{187,191 ; 192 ; 197 ; 199}$ Consensus-based guidelines have recently been published to assist authors, readers,

277 reviewers and journal editors on issues to report when developing or validating a prognostic model. ${ }^{204-206}$ When a model is already published, contacting the developers with a request for cooperation or additional information may help those who wish to further evaluate a model.

We have not described any assessment of the methodological conduct of the developed models and the quality of reporting of key methodological items. Although methodological quality of a model development study is - arguably - of less importance when a model shows good performance at external validation, the likelihood of developing a generalisable-generalizable model (which is not overfitted to the data on which the model is developed) is higher when recommended statistical methods have been used. ${ }^{1}$ Based on the large amount of prognostic modeling papers, clinicians and researchers

288 in obstetrics seem to be open to (the use of) prognostic models, but there should be 289 realization that it takes far more than just developing a model before patients can benefit 290 from it. Although most authors of the papers identified by our systematic review described

291 that accurate risk estimation would potentially have huge advantages, it remains unclear if 
292 using any of the identified models will truly impact clinical practice and contribute to

293 improvement of patient care. Thus, at this point, we cannot recommend the routine use of

294 any of the models. Given the potential benefits for timely prognostication and effective

295 management, it seems unfortunate that there is such a low number of applied models. The

296 Framingham risk score for future occurrence of cardiovascular disease, on which the

297 decision to start preventive interventions is based, is an example of a well-studied and

298 widely implemented prognostic model. ${ }^{207}$ Consequently, further investigation of model

299 validity and impact is important and should be undertaken.

300 In conclusion, in obstetrics many prognostic models are developed but there is

301 relatively little evidence about their performance, impact and usefulness in clinical practice.

302 New efforts in this context - or outside obstetrics - should be directed towards evaluating

303 the performance and impact of these existing models rather than developing new ones.

304 
307 (1) Steyerberg EW. Clinical Prediction Models. A practical approach to development, validation and updating. New York: Springer; 2009.

(2) Riley RD, Hayden JA, Steyerberg EW, Moons KG, Abrams K, Kyzas PA et al. Prognosis Research Strategy (PROGRESS) 2: prognostic factor research. PLoS Med 2013; 10(2):e1001380.

(3) APGAR V. A proposal for a new method of evaluation of the newborn infant. Curr Res Anesth Analg 1953; 32(4):260-267.

(4) BISHOP EH. Pelvic scoring for elective induction. Obstet Gynecol 1964; 24:266-268.

(5) Moons KG, Royston P, Vergouwe Y, Grobbee DE, Altman DG. Prognosis and prognostic research: what, why, and how? BMJ 2009; 338:b375.

(6) Moons KG, Altman DG, Vergouwe Y, Royston P. Prognosis and prognostic research: application and impact of prognostic models in clinical practice. BMJ 2009; 338:b606. Heart 2012; 98(9):691-698. 
(8) Moons KG, Kengne AP, Woodward M, Royston P, Vergouwe Y, Altman DG et al. Risk prediction models: I. Development, internal validation, and assessing the incremental value of a new (bio)marker. Heart 2012; 98(9):683-690.

(9) Ingui BJ, Rogers MA. Searching for clinical prediction rules in MEDLINE. J Am Med Inform Assoc 2001; 8(4):391-397.

(10) Abdelaziz A, Maher MA, Sayyed TM, Bazeed MF, Mohamed NS. Early pregnancy screening for hypertensive disorders in women without a-priori high risk. Ultrasound Obstet Gynecol 2012; 40(4):398-405.

(11) Akmal S, Kametas N, Tsoi E, Howard R, Nicolaides KH. Ultrasonographic occiput position in early labour in the prediction of caesarean section. BJOG 2004; 111(6):532-536.

(12) Akolekar R, Zaragoza E, Poon LC, Pepes S, Nicolaides KH. Maternal serum placental growth factor at $11+0$ to $13+6$ weeks of gestation in the prediction of preeclampsia. Ultrasound Obstet Gynecol 2008; 32(6):732-739.

(13) Akolekar R, Minekawa R, Veduta A, Romero XC, Nicolaides KH. Maternal plasma inhibin A at 11-13 weeks of gestation in hypertensive disorders of pregnancy. Prenat Diagn 2009; 29(8):753-760. 
(14) Akolekar R, Syngelaki A, Sarquis R, Zvanca M, Nicolaides KH. Prediction of early, intermediate and late pre-eclampsia from maternal factors, biophysical and biochemical markers at 11-13 weeks. Prenat Diagn 2011; 31(1):66-74.

(15) Ashoor G, Maiz N, Rotas M, Kametas NA, Nicolaides KH. Maternal thyroid function at 11 to 13 weeks of gestation and subsequent development of preeclampsia. Prenat Diagn 2010; 30(11):1032-1038.

(16) Audibert F, Boucoiran I, An N, Aleksandrov N, Delvin E, Bujold E et al. Screening for preeclampsia using first-trimester serum markers and uterine artery Doppler in nulliparous women. Am J Obstet Gynecol 2010; 203(4):383-388.

(17) August P, Helseth G, Cook EF, Sison C. A prediction model for superimposed preeclampsia in women with chronic hypertension during pregnancy. Am J Obstet Gynecol 2004; 191(5):1666-1672.

(18) Bachmann LM, Khan KS, Ogah J, Owen P. Multivariable analysis of tests for the diagnosis of intrauterine growth restriction. Ultrasound Obstet Gynecol 2003; 21(4):370-374.

(19) Bahado-Singh RO, Akolekar R, Mandal R, Dong E, Xia J, Kruger M et al. Metabolomics and first-trimester prediction of early-onset preeclampsia. J Matern Fetal Neonatal Med 2012; 25(10):1840-1847. 
(20) Bastek JA, Sammel MD, Srinivas SK, McShea MA, Foreman MN, Elovitz MA et al. Clinical prediction rules for preterm birth in patients presenting with preterm labor. Obstet Gynecol 2012; 119(6):1119-1128.

(21) Baumann P, Blackwell SC, Schild C, Berry SM, Friedrich HJ. Mathematic modeling to predict abruptio placentae. Am J Obstet Gynecol 2000; 183(4):815-822.

(22) Benjamin SJ, Daniel AB, Kamath A, Ramkumar V. Anthropometric measurements as predictors of cephalopelvic disproportion: Can the diagnostic accuracy be improved? Acta Obstet Gynecol Scand 2012; 91(1):122-127.

(23) Besinger RE, Compton AA, Hayashi RH. The presence or absence of fetal breathing movements as a predictor of outcome in preterm labor. Am J Obstet Gynecol 1987; 157(3):753-757.

(24) Beta J, Akolekar R, Ventura W, Syngelaki A, Nicolaides KH. Prediction of spontaneous preterm delivery from maternal factors, obstetric history and placental perfusion and function at 11-13 weeks. Prenat Diagn 2011; 31(1):75-83.

(25) Biguzzi E, Franchi F, Ambrogi F, Ibrahim B, Bucciarelli P, Acaia B et al. Risk factors for postpartum hemorrhage in a cohort of 6011 Italian women. Thromb Res 2012; 129(4):e1-e7.

(26) Block MF, Rahhal DK. Cervical incompetence. A diagnostic and prognostic scoring system. Obstet Gynecol 1976; 47(3):279-281. 
(27) Blondel B, Le C, X, Kaminski M, Chavigny C, Breart G, Sureau C. Prediction of preterm delivery: is it substantially improved by routine vaginal examinations? Am J Obstet Gynecol 1990; 162(4):1042-1048.

(28) Bouyer J, Papiernik E, Dreyfus J, Collin D, Winisdoerffer B, Gueguen S. Maturation signs of the cervix and prediction of preterm birth. Obstet Gynecol 1986; 68(2):209214.

(29) Broche DE, Ramanah R, Collin A, Mangin M, Vidal C, Maillet R et al. [Term-breech presentation: predictive factors of cesarean section for vaginal-birth failure]. J Gynecol Obstet Biol Reprod (Paris) 2008; 37(5):483-492.

(30) Bueno B, San-Frutos L, Perez-Medina T, Barbancho C, Troyano J, Bajo J. The labor induction: integrated clinical and sonographic variables that predict the outcome. J Perinatol 2007; 27(1):4-8.

(31) Catley C, Frize M, Walker CR, Petriu DC. Predicting high-risk preterm birth using artificial neural networks. IEEE Trans Inf Technol Biomed 2006; 10(3):540-549.

(32) Celik E, To M, Gajewska K, Smith GC, Nicolaides KH. Cervical length and obstetric history predict spontaneous preterm birth: development and validation of a model to provide individualized risk assessment. Ultrasound Obstet Gynecol 2008; 31(5):549554. 
(33) Chan LY, Leung TY, Fok WY, Chan LW, Lau TK. Prediction of successful vaginal delivery in women undergoing external cephalic version at term for breech presentation. Eur J Obstet Gynecol Reprod Biol 2004; 116(1):39-42.

(34) Cobo T, Kacerovsky M, Holst RM, Hougaard DM, Skogstrand K, Wennerholm UB et al. Intra-amniotic inflammation predicts microbial invasion of the amniotic cavity but not spontaneous preterm delivery in preterm prelabor membrane rupture. Acta Obstet Gynecol Scand 2012; 91(8):930-935.

(35) de Caunes F, Alexander GR, Berchel C, Guengant JP, Papiernik E. Anamnestic pregnancy risk assessment. Int J Gynaecol Obstet 1990; 33(3):221-227.

(36) de Oliveira RV, Martins MG, Rios LT, Araujo JE, Simoes VM, Nardozza LM et al. Predictive model for spontaneous preterm labor among pregnant women with contractions and intact amniotic membranes. Arch Gynecol Obstet 2012; 286(4):893900.

(37) De Paco C, Kametas N, Rencoret G, Strobl I, Nicolaides KH. Maternal cardiac output between 11 and 13 weeks of gestation in the prediction of preeclampsia and small for gestational age. Obstet Gynecol 2008; 111(2 Pt 1):292-300.

(38) Di Lorenzo G, Ceccarello M, Cecotti V, Ronfani L, Monasta L, Vecchi BL et al. First trimester maternal serum PIGF, free beta-hCG, PAPP-A, PP-13, uterine artery Doppler and maternal history for the prediction of preeclampsia. Placenta 2012; 33(6):495501. 
414 (39) Dietz HP, Lanzarone V, Simpson JM. Predicting operative delivery. Ultrasound Obstet Gynecol 2006; 27(4):409-415.

(40) Dodd JM, Catcheside B, Scheil W. Can shoulder dystocia be reliably predicted? Aust N Z J Obstet Gynaecol 2012; 52(3):248-252.

(41) Doherty DA, James IR, Newnham JP. Estimation of the Doppler ultrasound umbilical maximal waveform envelope: II. Prediction of fetal distress. Ultrasound Med Biol 2002; 28(10):1261-1270.

(42) Dugoff L, Cuckle HS, Hobbins JC, Malone FD, Belfort MA, Nyberg DA et al. Prediction of patient-specific risk for fetal loss using maternal characteristics and first- and second-trimester maternal serum Down syndrome markers. Am J Obstet Gynecol 2008; 199(3):290-296.

(43) Dulitzki M, Soriano D, Schiff E, Chetrit A, Mashiach S, Seidman DS. Effect of very advanced maternal age on pregnancy outcome and rate of cesarean delivery. Obstet Gynecol 1998; 92(6):935-939.

(44) Elaveyini U, Devi SP, Rao KS. Neural networks prediction of preterm delivery with first trimester bleeding. Arch Gynecol Obstet 2011; 283(5):971-979. maternal predisposition to preeclampsia. Hypertens Pregnancy 2008; 27(3):237-245. 
(46) Esplin MS, O'Brien E, Fraser A, Kerber RA, Clark E, Simonsen SE et al. Estimating recurrence of spontaneous preterm delivery. Obstet Gynecol 2008; 112(3):516-523.

(47) Esplin MS, Merrell K, Goldenberg R, Lai Y, lams JD, Mercer B et al. Proteomic identification of serum peptides predicting subsequent spontaneous preterm birth. Am J Obstet Gynecol 2011; 204(5):391-398.

(48) Faber R, Viehweg B, Hiller K. [Discriminant analytic model for prognostic assessment of pregnancies at risk for premature labor]. Z Geburtshilfe Neonatol 1995; 199(2):4853.

(49) Farina A, Zucchini C, Sekizawa A, Purwosunu Y, De SP, Santarsiero G et al. Performance of messenger RNAs circulating in maternal blood in the prediction of preeclampsia at 10-14 weeks. Am J Obstet Gynecol 2010; 203(6):575-577.

(50) Fuchs F, Senat MV, Fernandez H, Gervaise A, Frydman R, Bouyer J. Predictive score for early preterm birth in decisions about emergency cervical cerclage in singleton pregnancies. Acta Obstet Gynecol Scand 2012; 91(6):744-749.

(51) Garcia-Patterson A, Erdozain L, Ginovart G, Adelantado JM, Cubero JM, Gallo G et al. In human gestational diabetes mellitus congenital malformations are related to prepregnancy body mass index and to severity of diabetes. Diabetologia 2004; 47(3):509-514. 
(52) Giannella L, Beraldi R, Giulini S, Cerami LB, Mfuta K, Facchinetti F. Nitric oxide metabolite levels and assessment of cervical length in the prediction of preterm delivery among women undergoing symptomatic preterm labor. Int J Gynaecol Obstet 2012; 116(3):223-227.

(53) Goetzinger KR, Singla A, Gerkowicz S, Dicke JM, Gray DL, Odibo AO. Predicting the risk of pre-eclampsia between 11 and 13 weeks' gestation by combining maternal characteristics and serum analytes, PAPP-A and free beta-hCG. Prenat Diagn 2010; 30(12-13):1138-1142.

(54) Goldenberg RL, lams JD, Mercer BM, Meis PJ, Moawad A, Das A et al. The Preterm Prediction Study: toward a multiple-marker test for spontaneous preterm birth. Am J Obstet Gynecol 2001; 185(3):643-651.

(55) Gomez-Laencina AM, Garcia CP, Asensio LV, Ponce JA, Martinez MS, MartinezVizcaino V. Sonographic cervical length as a predictor of type of delivery after induced labor. Arch Gynecol Obstet 2012; 285(6):1523-1528.

(56) Gonen R, Tamir A, Degani S, Ohel G. Variables associated with successful vaginal birth after one cesarean section: a proposed vaginal birth after cesarean section score. Am J Perinatol 2004; 21(8):447-453.

(57) Goodwin LK, lannacchione MA, Hammond WE, Crockett P, Maher S, Schlitz K. Data mining methods find demographic predictors of preterm birth. Nurs Res 2001; $50(6): 340-345$. 
470 (58) Greco E, Gupta R, Syngelaki A, Poon LC, Nicolaides KH. First-trimester screening for spontaneous preterm delivery with maternal characteristics and cervical length. Fetal Diagn Ther 2012; 31(3):154-161.

(59) Grobman WA, Lai Y, Landon MB, Spong CY, Leveno KJ, Rouse DJ et al. Development of a nomogram for prediction of vaginal birth after cesarean delivery. Obstet Gynecol $2007 ; 109(4): 806-812$.

(60) Grobman WA, Lai Y, Landon MB, Spong CY, Leveno KJ, Rouse DJ et al. Does information available at admission for delivery improve prediction of vaginal birth after cesarean? Am J Perinatol 2009; 26(10):693-701.

(61) Gross TL, Sokol RJ, Williams T, Thompson K. Shoulder dystocia: a fetal-physician risk. Am J Obstet Gynecol 1987; 156(6):1408-1418.

(62) Grzymala-Busse JW, Woolery LK. Improving prediction of preterm birth using a new classification scheme and rule induction. Proc Annu Symp Comput Appl Med Care $1994 ; 730-734$.

(63) Gupta M, Hockley C, Quigley MA, Yeh P, Impey L. Antenatal and intrapartum prediction of shoulder dystocia. Eur J Obstet Gynecol Reprod Biol 2010; 151(2):134139.

(64) Guzick DS, Daikoku NH, Kaltreider DF. Predictability of pregnancy outcome in preterm delivery. Obstet Gynecol 1984; 63(5):645-650. 
(65) Harrington K, Carpenter RG, Goldfrad C, Campbell S. Transvaginal Doppler ultrasound of the uteroplacental circulation in the early prediction of pre-eclampsia and intrauterine growth retardation. Br J Obstet Gynaecol 1997; 104(6):674-681.

(66) Hashima JN, Guise JM. Vaginal birth after cesarean: a prenatal scoring tool. Am J Obstet Gynecol 2007; 196(5):e22-e23.

(67) Herman A, Groutzd A, Bukovsky I, Arieli S, Sherman D, Caspi E. A simplified preinduction scoring method for the prediction of successful vaginal delivery based on multivariate analysis of pelvic and other obstetrical factors. J Perinat Med 1993; 21(2):117-124.

(68) Hoirisch-Clapauch S, Benchimol-Barbosa PR. Markers of insulin resistance and sedentary lifestyle are predictors of preeclampsia in women with adverse obstetric results. Braz J Med Biol Res 2011; 44(12):1285-1290.

(69) Holst RM, Hagberg H, Wennerholm UB, Skogstrand K, Thorsen P, Jacobsson B. Prediction of spontaneous preterm delivery in women with preterm labor: analysis of multiple proteins in amniotic and cervical fluids. Obstet Gynecol 2009; 114(2 Pt 1):268-277.

(70) Hueston WJ. Preterm contractions in community settings: II. Predicting preterm birth in women with preterm contractions. Obstet Gynecol 1998; 92(1):43-46. 
507

508

509

510

511

512

513
(71) Isono W, Nagamatsu T, Uemura Y, Fujii T, Hyodo H, Yamashita T et al. Prediction model for the incidence of emergent cesarean section during induction of labor specialized in nulliparous low-risk women. J Obstet Gynaecol Res 2011; 37(12):17841791.

(72) Jakobi P, Weissman A, Peretz BA, Hocherman I. Evaluation of prognostic factors for vaginal delivery after cesarean section. J Reprod Med 1993; 38(9):729-733.

(73) Jung HJ, Park KH, Kim SN, Hong JS, Oh KJ, Kim G et al. Non-invasive prediction of intra-amniotic inflammation in women with preterm labor. Ultrasound Obstet Gynecol 2011; 37(1):82-87.

(74) Kambale MJ. Social predictors of caesarean section births in Italy. Afr Health Sci 2011; 11(4):560-565.

(75) Karagiannis G, Akolekar R, Sarquis R, Wright D, Nicolaides KH. Prediction of small-forgestation neonates from biophysical and biochemical markers at 11-13 weeks. Fetal Diagn Ther 2011; 29(2):148-154.

(76) Kayem G, Maillard F, Schmitz T, Jarreau PH, Cabrol D, Breart G et al. Prediction of clinical infection in women with preterm labour with intact membranes: a score based on ultrasonographic, clinical and biological markers. Eur J Obstet Gynecol Reprod Biol 2009; 145(1):36-40. 
(77) Kenny LC, Broadhurst DI, Dunn W, Brown M, North RA, McCowan L et al. Robust early pregnancy prediction of later preeclampsia using metabolomic biomarkers. Hypertension 2010; 56(4):741-749.

(78) Khalil A, Akolekar R, Syngelaki A, Elkhouli M, Nicolaides KH. Maternal hemodynamics at 11-13 weeks' gestation and risk of pre-eclampsia. Ultrasound Obstet Gynecol $2012 ; 40(1): 28-34$

(79) Khaw A, Kametas NA, Turan OM, Bamfo JE, Nicolaides KH. Maternal cardiac function and uterine artery Doppler at 11-14 weeks in the prediction of pre-eclampsia in nulliparous women. BJOG 2008; 115(3):369-376.

(80) Kiefer DG, Keeler SM, Rust O, Chow SS, Craig ME, Peltier MR et al. Amniotic fluid inflammatory score is associated with pregnancy outcome in patients with mid trimester short cervix. Am J Obstet Gynecol 2012; 206(1):68-6.

(81) Kim SN, Park KH, Jung HJ, Hong JS, Shin DM, Kang WS. Clinical and sonographic parameters at 37 weeks' gestation for predicting the risk of primary Cesarean delivery in nulliparous women. Ultrasound Obstet Gynecol 2010; 36(4):486-492.

(82) Kok M, van der Steeg JW, van der Post JA, Mol BW. Prediction of success of external cephalic version after 36 weeks. Am J Perinatol 2011; 28(2):103-110. 
(83) Koopmans CM, Zwart JJ, Groen H, Bloemenkamp KW, Mol BW, van Pampus MG et al. Risk indicators for eclampsia in gestational hypertension or mild preeclampsia at term. Hypertens Pregnancy 2011; 30(4):433-446.

(84) Kraiem J, Ben BY, Chaabane K, Sarraj N, Chiha N, Falfoul A. [Indicators for successful vaginal delivery after cesarean section: a proposal of a predictive score]. Tunis Med 2006; 84(1):16-20.

(85) Kurkinen-Raty M, Ruokonen A, Vuopala S, Koskela M, Rutanen EM, Karkkainen T et al. Combination of cervical interleukin- 6 and -8 , phosphorylated insulin-like growth factor-binding protein-1 and transvaginal cervical ultrasonography in assessment of the risk of preterm birth. BJOG 2001; 108(8):875-881.

(86) Lambert-Messerlian GM, Silver HM, Petraglia F, Luisi S, Pezzani I, Maybruck WM et al. Second-trimester levels of maternal serum human chorionic gonadotropin and inhibin a as predictors of preeclampsia in the third trimester of pregnancy. J Soc Gynecol Investig 2000; 7(3):170-174.

(87) Larsen WI, Strong JE, Farley JH. Risk factors for late postpartum preeclampsia. J Reprod Med 2012; 57(1-2):35-38.

(88) Latendresse G, Ruiz RJ. Maternal coping style and perceived adequacy of income predict CRH levels at 14-20 weeks of gestation. Biol Res Nurs 2010; 12(2):125-136. 
560 (89) Lau TK, Lo KW, Wan D, Rogers MS. Predictors of successful external cephalic version at term: a prospective study. Br J Obstet Gynaecol 1997; 104(7):798-802.

562 (90) Laughon SK, Zhang J, Troendle J, Sun L, Reddy UM. Using a simplified Bishop score to predict vaginal delivery. Obstet Gynecol 2011; 117(4):805-811.

564 (91) Lee KA, Chang MH, Park MH, Park H, Ha EH, Park EA et al. A model for prediction of spontaneous preterm birth in asymptomatic women. J Womens Health (Larchmt ) $2011 ; 20(12): 1825-1831$.

(92) Lee LC, Sheu BC, Shau WY, Liu DM, Lai TJ, Lee YH et al. Mid-trimester beta-hCG levels incorporated in a multifactorial model for the prediction of severe pre-eclampsia. Prenat Diagn 2000; 20(9):738-743.

(93) Levine MG, Holroyde J, Woods JR, Jr., Siddiqi TA, Scott M, Miodovnik M. Birth trauma: incidence and predisposing factors. Obstet Gynecol 1984; 63(6):792-795.

(94) Lindqvist PG, Kublikas M, Dahlback B. Individual risk assessment of thrombosis in pregnancy. Acta Obstet Gynecol Scand 2002; 81(5):412-416. Gynecol Reprod Biol 2006; 126(2):160-164. 
(96) Liu CM, Chang SD, Cheng PJ. Prediction of fetal birthweight in Taiwanese women with pre-eclampsia and gestational hypertension using an equation based on maternal characteristics. J Obstet Gynaecol Res 2008; 34(4):480-486.

(97) Macones GA, Segel SY, Stamilio DM, Morgan MA. Prediction of delivery among women with early preterm labor by means of clinical characteristics alone. Am J Obstet Gynecol 1999; 181(6):1414-1418.

(98) Macones GA, Segel SY, Stamilio DM, Morgan MA. Predicting delivery within 48 hours in women treated with parenteral tocolysis. Obstet Gynecol 1999; 93(3):432-436.

(99) Macones GA, Cahill AG, Stamilio DM, Odibo A, Peipert J, Stevens EJ. Can uterine rupture in patients attempting vaginal birth after cesarean delivery be predicted? Am J Obstet Gynecol 2006; 195(4):1148-1152.

(100) Magann EF, Doherty DA, Chauhan SP, Klimpel JM, Huff SD, Morrison JC. Pregnancy, obesity, gestational weight gain, and parity as predictors of peripartum complications. Arch Gynecol Obstet 2011; 284(4):827-836.

(101) Mamelle N, Cochet V, Claris O. Definition of fetal growth restriction according to constitutional growth potential. Biol Neonate 2001; 80(4):277-285.

(102) Mara M, Dohnalova A, Zizka Z, Haakova L, Hajek Z, Calda P et al. [Prediction of premature labor--multifactorial analysis of a prospective clinical study]. Ceska Gynekol 2002; 67(2):58-65. 
(103) Masse J, Forest JC, Moutquin JM, Marcoux S, Brideau NA, Belanger M. A prospective study of several potential biologic markers for early prediction of the development of preeclampsia. Am J Obstet Gynecol 1993; 169(3):501-508.

(104) Mbele AM, Makin JD, Pattinson RC. Can the outcome of induction of labour with oral misoprostol be predicted. S Afr Med J 2007; 97(4):289-292.

(105) McLean M, Bisits A, Davies J, Walters W, Hackshaw A, De VK et al. Predicting risk of preterm delivery by second-trimester measurement of maternal plasma corticotropin-releasing hormone and alpha-fetoprotein concentrations. Am J Obstet Gynecol 1999; 181(1):207-215.

(106) Mello G, Parretti E, Ognibene A, Mecacci F, Cioni R, Scarselli G et al. Prediction of the development of pregnancy-induced hypertensive disorders in high-risk pregnant women by artificial neural networks. Clin Chem Lab Med 2001; 39(9):801-805.

(107) Mello G, Parretti E, Cioni R, Lagozio C, Mealli F, Pratesi M. Individual longitudinal patterns in biochemical and hematological markers for the early prediction of preeclampsia. J Matern Fetal Neonatal Med 2002; 11(2):93-99.

(108) Mercer BM, Goldenberg RL, Das A, Moawad AH, lams JD, Meis PJ et al. The preterm prediction study: a clinical risk assessment system. Am J Obstet Gynecol 1996; 174(6):1885-1893. 
613
(109) Myatt L, Clifton RG, Roberts JM, Spong CY, Hauth JC, Varner MW et al. First-Trimester Prediction of Preeclampsia in Nulliparous Women at Low Risk. Obstet Gynecol 2012; 119(6):1234-1242.

(110) Nader R, Shek KL, Dietz HP. Predicting the outcome of induction of labour. Aust N Z J Obstet Gynaecol 2010; 50(4):329-333.

(111) Nanda S, Savvidou M, Syngelaki A, Akolekar R, Nicolaides KH. Prediction of gestational diabetes mellitus by maternal factors and biomarkers at 11 to 13 weeks. Prenat Diagn 2011; 31(2):135-141.

(112) Newman RB, Peacock BS, Vandorsten JP, Hunt HH. Predicting success of external cephalic version. Am J Obstet Gynecol 1993; 169(2 Pt 1):245-249.

(113) Nicholson W, Croughan-Minihane M, Posner S, Washington AE, Kilpatrick SK. Preterm delivery in patients admitted with preterm labor: a prediction study. J Matern Fetal Med 2001; 10(2):102-106.

(114) North RA, McCowan LM, Dekker GA, Poston L, Chan EH, Stewart AW et al. Clinical risk prediction for pre-eclampsia in nulliparous women: development of model in international prospective cohort. BMJ 2011; 342:d1875.

(115) Odibo AO, Farrell C, Macones GA, Berghella V. Development of a scoring system for predicting the risk of preterm birth in women receiving cervical cerclage. J Perinatol $2003 ; 23(8): 664-667$. 
632

(116) Odibo AO, Cahill AG, Stamilio DM, Stevens EJ, Peipert JF, Macones GA. Predicting placental abruption and previa in women with a previous cesarean delivery. Am J Perinatol 2007; 24(5):299-305.

(117) Odibo AO, Goetzinger KR, Odibo L, Cahill AG, Macones GA, Nelson DM et al. Firsttrimester prediction of preeclampsia using metabolomic biomarkers: a discovery phase study. Prenat Diagn 2011; 31(10):990-994.

(118) Odibo AO, Zhong Y, Goetzinger KR, Odibo L, Bick JL, Bower CR et al. First-trimester placental protein 13, PAPP-A, uterine artery Doppler and maternal characteristics in the prediction of pre-eclampsia. Placenta 2011; 32(8):598-602.

(119) Onderdonk AB, Lee ML, Lieberman E, Delaney ML, Tuomala RE. Quantitative microbiologic models for preterm delivery. J Clin Microbiol 2003; 41(3):1073-1079.

(120) Onwudiwe N, Yu CK, Poon LC, Spiliopoulos I, Nicolaides KH. Prediction of preeclampsia by a combination of maternal history, uterine artery Doppler and mean arterial pressure. Ultrasound Obstet Gynecol 2008; 32(7):877-883.

(121) Papageorghiou AT, Yu CK, Erasmus IE, Cuckle HS, Nicolaides KH. Assessment of risk for the development of pre-eclampsia by maternal characteristics and uterine artery Doppler. BJOG 2005; 112(6):703-709. 
649

650

651

652

653

654

655

656

657

658

659

660

661

662

663

664

665

666
(122) Park KH, Lee SY, Kim SN, Jeong EH, Oh KJ, Ryu A. Prediction of imminent preterm delivery in women with preterm premature rupture of membranes. J Perinat Med $2011 ; 40(2): 151-157$.

(123) Park KH, Kim SN, Oh KJ, Lee SY, Jeong EH, Ryu A. Noninvasive Prediction of IntraAmniotic Infection and/or Inflammation in Preterm Premature Rupture of Membranes. Reprod Sci 2012; 19(6):658-665.

(124) Pascual-Ramirez J, Haya J, Perez-Lopez F, Gil TS. Type of axial analgesia does not influence time to vaginal delivery in a Proportional Hazards Model. Arch Gynecol Obstet 2012; 286(4):873-880.

(125) Pearce BD, Grove J, Bonney EA, Bliwise N, Dudley DJ, Schendel DE et al. Interrelationship of cytokines, hypothalamic-pituitary-adrenal axis hormones, and psychosocial variables in the prediction of preterm birth. Gynecol Obstet Invest 2010; $70(1): 40-46$

(126) Pertot T, Molyneaux L, Tan K, Ross GP, Yue DK, Wong J. Can common clinical parameters be used to identify patients who will need insulin treatment in gestational diabetes mellitus? Diabetes Care 2011; 34(10):2214-2216.

(127) Phaloprakarn C, Tangjitgamol S. Risk assessment for preeclampsia in women with gestational diabetes mellitus. J Perinat Med 2009; 37(6):617-621. 
667

668

669

670

671

672

673

674

675

676

677

678

679

680

681

682

683

684

685
(128) Phaloprakarn C, Tangjitgamol S, Manusirivithaya S. A risk score for selective screening for gestational diabetes mellitus. Eur J Obstet Gynecol Reprod Biol 2009; 145(1):7175.

(129) Pilalis A, Souka AP, Antsaklis P, Daskalakis G, Papantoniou N, Mesogitis S et al. Screening for pre-eclampsia and fetal growth restriction by uterine artery Doppler and PAPP-A at 11-14 weeks' gestation. Ultrasound Obstet Gynecol 2007; 29(2):135140.

(130) Pitarello P, Tadashi YC, Ruano R, Zugaib M. Prediction of successful labor induction using transvaginal sonographic cervical measurements. J Clin Ultrasound 2013; 41(2):76-83.

(131) Plasencia W, Maiz N, Bonino S, Kaihura C, Nicolaides KH. Uterine artery Doppler at 11 +0 to $13+6$ weeks in the prediction of pre-eclampsia. Ultrasound Obstet Gynecol 2007; 30(5):742-749.

(132) Plasencia W, Maiz N, Poon L, Yu C, Nicolaides KH. Uterine artery Doppler at $11+0$ to $13+6$ weeks and $21+0$ to $24+6$ weeks in the prediction of pre-eclampsia Ultrasound Obstet Gynecol 2008; 32(2):138-146.

(133) Poon LC, Kametas NA, Pandeva I, Valencia C, Nicolaides KH. Mean arterial pressure at $11(+0)$ to $13(+6)$ weeks in the prediction of preeclampsia. Hypertension 2008; 51(4):1027-1033. 
686

687

688

689

690

691

692

693

694

695

696

697

698

699

700

701

702
(134) Poon LC, Kametas NA, Maiz N, Akolekar R, Nicolaides KH. First-trimester prediction of hypertensive disorders in pregnancy. Hypertension 2009; 53(5):812-818.

(135) Poon LC, Karagiannis G, Leal A, Romero XC, Nicolaides KH. Hypertensive disorders in pregnancy: screening by uterine artery Doppler imaging and blood pressure at $11-13$ weeks. Ultrasound Obstet Gynecol 2009; 34(5):497-502.

(136) Poon LC, Maiz N, Valencia C, Plasencia W, Nicolaides KH. First-trimester maternal serum pregnancy-associated plasma protein-A and pre-eclampsia. Ultrasound Obstet Gynecol 2009; 33(1):23-33.

(137) Poon LC, Akolekar R, Lachmann R, Beta J, Nicolaides KH. Hypertensive disorders in pregnancy: screening by biophysical and biochemical markers at 11-13 weeks. Ultrasound Obstet Gynecol 2010; 35(6):662-670.

(138) Poon LC, Kametas NA, Chelemen T, Leal A, Nicolaides KH. Maternal risk factors for hypertensive disorders in pregnancy: a multivariate approach. J Hum Hypertens 2010; 24(2):104-110.

(139) Poon LC, Karagiannis G, Staboulidou I, Shafiei A, Nicolaides KH. Reference range of birth weight with gestation and first-trimester prediction of small-for-gestation neonates. Prenat Diagn 2011; 31(1):58-65. 
703

(140) Prata N, Hamza S, Bell S, Karasek D, Vahidnia F, Holston M. Inability to predict postpartum hemorrhage: insights from Egyptian intervention data. BMC Pregnancy Childbirth 2011; 11:97.

(141) Ramos-Levi AM, Perez-Ferre N, Fernandez MD, Del Valle L, Bordiu E, Bedia AR et al. Risk factors for gestational diabetes mellitus in a large population of women living in Spain: implications for preventative strategies. Int J Endocrinol 2012; 2012:312529.

(142) Rane SM, Pandis GK, Guirgis RR, Higgins B, Nicolaides KH. Pre-induction sonographic measurement of cervical length in prolonged pregnancy: the effect of parity in the prediction of induction-to-delivery interval. Ultrasound Obstet Gynecol 2003; 22(1):40-44

(143) Rane SM, Guirgis RR, Higgins B, Nicolaides KH. The value of ultrasound in the prediction of successful induction of labor. Ultrasound Obstet Gynecol 2004; 24(5):538-549.

(144) Rane SM, Guirgis RR, Higgins B, Nicolaides KH. Models for the prediction of successful induction of labor based on pre-induction sonographic measurement of cervical length. J Matern Fetal Neonatal Med 2005; 17(5):315-322.

(145) Rao A, Celik E, Poggi S, Poon L, Nicolaides KH. Cervical length and maternal factors in expectantly managed prolonged pregnancy: prediction of onset of labor and mode of delivery. Ultrasound Obstet Gynecol 2008; 32(5):646-651. 
(146) Reddy UM, Laughon SK, Sun L, Troendle J, Willinger M, Zhang J. Prepregnancy risk factors for antepartum stillbirth in the United States. Obstet Gynecol 2010; 116(5):1119-1126.

(147) Riboni F, Garofalo G, Pascoli I, Vitulo A, Dell'Avanzo M, Battagliarin G et al. Labour induction at term: clinical, biophysical and molecular predictive factors. Arch Gynecol Obstet 2012; 286(5):1123-1129.

(148) Robinson CJ, Hill EG, Alanis MC, Chang EY, Johnson DD, Almeida JS. Examining the effect of maternal obesity on outcome of labor induction in patients with preeclampsia. Hypertens Pregnancy 2010; 29(4):446-456.

(149) Roman H, Carayol M, Watier L, Le RC, Breart G, Goffinet F. Planned vaginal delivery of fetuses in breech presentation at term: prenatal determinants predictive of elevated risk of cesarean delivery during labor. Eur J Obstet Gynecol Reprod Biol 2008; 138(1):14-22.

(150) Romero GG, Aguilar B, I, Chavez CA, Ponce Ponce de Leon AL. [Prediction of fetal wellbeing with Doppler flowmetric profile in pregnant hypertensive women]. Ginecol Obstet Mex 2001; 69:480-486.

(151) Ross MG, Hobel CJ, Bragonier JR, Bear MB, Bemis RL. A simplified risk-scoring system for prematurity. Am J Perinatol 1986; 3(4):339-344. 
(152) Ruiz RJ, Fullerton J, Brown CE, Dudley DJ. Predicting risk of preterm birth: the roles of stress, clinical risk factors, and corticotropin-releasing hormone. Biol Res Nurs 2002; $4(1): 54-64$

(153) Savvidou M, Nelson SM, Makgoba M, Messow CM, Sattar N, Nicolaides K. Firsttrimester prediction of gestational diabetes mellitus: examining the potential of combining maternal characteristics and laboratory measures. Diabetes 2010; 59(12):3017-3022.

(154) Schuit E, Kwee A, Westerhuis M, Van DH, Graziosi G, Van LJ et al. A clinical prediction model to assess the risk of operative delivery. BJOG 2012; 119(8):915-923.

(155) Scifres CM, Rohn A, Odibo A, Stamilio D, Macones GA. Predicting significant maternal morbidity in women attempting vaginal birth after cesarean section. Am J Perinatol $2011 ; 28(3): 181-186$.

(156) Seed PT, Chappell LC, Black MA, Poppe KK, Hwang YC, Kasabov N et al. Prediction of preeclampsia and delivery of small for gestational age babies based on a combination of clinical risk factors in high-risk women. Hypertens Pregnancy 2011; 30(1):58-73.

(157) Sekizawa A, Purwosunu Y, Farina A, Shimizu H, Nakamura M, Wibowo N et al. Prediction of pre-eclampsia by an analysis of placenta-derived cellular mRNA in the blood of pregnant women at 15-20 weeks of gestation. BJOG 2010; 117(5):557-564. 
758
(158) Smith GC, White IR, Pell JP, Dobbie R. Predicting cesarean section and uterine rupture among women attempting vaginal birth after prior cesarean section. PLoS Med 2005; 2(9):e252.

(159) Smith GC, Shah I, White IR, Pell JP, Crossley JA, Dobbie R. Maternal and biochemical predictors of spontaneous preterm birth among nulliparous women: a systematic analysis in relation to the degree of prematurity. Int J Epidemiol 2006; 35(5):11691177.

(160) Smith GC, Yu CK, Papageorghiou AT, Cacho AM, Nicolaides KH. Maternal uterine artery Doppler flow velocimetry and the risk of stillbirth. Obstet Gynecol 2007; 109(1):144-151.

(161) Snidvongs W, Bhongsvej S, Witoonpanich P, Thaitumyanond P, Charoenvidhya D, Wiswasukmongkol V et al. Intrauterine growth retardation: incidence, screening results, pregnancy outcome. J Med Assoc Thai 1989; 72(7):387-394.

(162) Souka AP, Papastefanou I, Michalitsi V, Papadopoulos GK, Kassanos D. A predictive model of short cervix at 20-24 weeks using first-trimester cervical length measurement and maternal history. Prenat Diagn 2011; 31(2):202-206.

(163) Srinivas SK, Stamilio DM, Stevens EJ, Odibo AO, Peipert JF, Macones GA. Predicting failure of a vaginal birth attempt after cesarean delivery. Obstet Gynecol 2007; 109(4):800-805. 
(164) Stamilio DM, Sehdev HM, Morgan MA, Propert K, Macones GA. Can antenatal clinical and biochemical markers predict the development of severe preeclampsia? Am J Obstet Gynecol 2000; 182(3):589-594.

(165) Tan H, Wen SW, Chen XK, Demissie K, Walker M. Early prediction of preterm birth for singleton, twin, and triplet pregnancies. Eur J Obstet Gynecol Reprod Biol 2007; 131(2):132-137.

(166) Teede HJ, Harrison CL, Teh WT, Paul E, Allan CA. Gestational diabetes: development of an early risk prediction tool to facilitate opportunities for prevention. Aust N Z J Obstet Gynaecol 2011; 51(6):499-504.

(167) To MS, Skentou CA, Royston P, Yu CK, Nicolaides KH. Prediction of patient-specific risk of early preterm delivery using maternal history and sonographic measurement of cervical length: a population-based prospective study. Ultrasound Obstet Gynecol $2006 ; 27(4): 362-367$.

(168) Tomoda S, Tamura T, Kitanaka T, Ogita S. First trimester biological markers for the prediction of pregnancy-induced hypertension. Am J Perinatol 1996; 13(2):89-93.

(169) Tsiartas P, Holst RM, Wennerholm UB, Hagberg H, Hougaard DM, Skogstrand K et al. Prediction of spontaneous preterm delivery in women with threatened preterm labour: a prospective cohort study of multiple proteins in maternal serum. BJOG $2012 ; 119(7): 866-873$. 
(170) Tsu VD. Antenatal screening: its use in assessing obstetric risk factors in Zimbabwe. J Epidemiol Community Health 1994; 48(3):297-305.

(171) van der Tuuk K, Koopmans CM, Groen H, Aarnoudse JG, van den Berg PP, van Beek JJ et al. Prediction of progression to a high risk situation in women with gestational hypertension or mild pre-eclampsia at term. Aust N Z J Obstet Gynaecol 2011; $51(4): 339-346$.

(172) van Kuijk SM, Nijdam ME, Janssen KJ, Sep SJ, Peeters LL, Delahaije DH et al. A model for preconceptional prediction of recurrent early-onset preeclampsia: derivation and internal validation. Reprod Sci 2011; 18(11):1154-1159.

(173) van Leeuwen M, Opmeer BC, Zweers EJ, van BE, ter Brugge HG, de Valk HW et al. Estimating the risk of gestational diabetes mellitus: a clinical prediction model based on patient characteristics and medical history. BJOG 2010; 117(1):69-75.

(174) van Ravenswaaij R, Tesselaar-van der Goot M, de WS, van Leeuwen-Spruijt M, Visser GH, Schielen PC. First-trimester serum PAPP-A and fbeta-hCG concentrations and other maternal characteristics to establish logistic regression-based predictive rules for adverse pregnancy outcome. Prenat Diagn 2011; 31(1):50-57.

(175) Vogel I, Grove J, Thorsen P, Moestrup SK, Uldbjerg N, Moller HJ. Preterm delivery predicted by soluble CD163 and CRP in women with symptoms of preterm delivery. BJOG 2005; 112(6):737-742. 
815

(182) Wong WM, Lao TT, Liu KL. Predicting the success of external cephalic version with a

(176) von Dadelszen P, Payne B, Li J, Ansermino JM, Broughton PF, Cote AM et al. Prediction of adverse maternal outcomes in pre-eclampsia: development and validation of the fullPIERS model. Lancet 2011; 377(9761):219-227.

(177) Weenink GH, Treffers PE, Vijn P, Smorenberg-Schoorl ME, Ten Cate JW. Antithrombin III levels in preeclampsia correlate with maternal and fetal morbidity. Am J Obstet Gynecol 1984; 148(8):1092-1097.

(178) Weiner CP, Sabbagha RE, Vaisrub N, Socol ML. Ultrasonic fetal weight prediction: role of head circumference and femur length. Obstet Gynecol 1985; 65(6):812-817.

(179) Weinstein D, Benshushan A, Tanos V, Zilberstein R, Rojansky N. Predictive score for vaginal birth after cesarean section. Am J Obstet Gynecol 1996; 174(1 Pt 1):192-198.

(180) Williams A, Tincello DG, White S, Adams EJ, Alfirevic Z, Richmond DH. Risk scoring system for prediction of obstetric anal sphincter injury. BJOG 2005; 112(8):10661069.

(181) Wing DA, Tran S, Paul RH. Factors affecting the likelihood of successful induction after intravaginal misoprostol application for cervical ripening and labor induction. Am J Obstet Gynecol 2002; 186(6):1237-1240. scoring system. A prospective, two-phase study. J Reprod Med 2000; 45(3):201-206. 
833 (183) Woolery LK, Grzymala-Busse J. Machine learning for development of an expert system to predict premature birth. Biomed Sci Instrum 1995; 31:29-34.

835

836

837

838

839

840

841

842

843

844

845

846

847

(184) Youssef A, Righetti F, Morano D, Rizzo N, Farina A. Uterine artery Doppler and biochemical markers (PAPP-A, PIGF, sFlt-1, P-selectin, NGAL) at $11+0$ to $13+6$ weeks in the prediction of late (> 34 weeks) pre-eclampsia. Prenat Diagn 2011; 31(12):11411146.

(185) Yu CK, Smith GC, Papageorghiou AT, Cacho AM, Nicolaides KH. An integrated model for the prediction of preeclampsia using maternal factors and uterine artery Doppler velocimetry in unselected low-risk women. Am J Obstet Gynecol 2005; 193(2):429436.

(186) Zhou J, Zhao X, Wang Z, Hu Y. Combination of lipids and uric acid in mid-second trimester can be used to predict adverse pregnancy outcomes. J Matern Fetal Neonatal Med 2012; 25(12):2633-2638.

(187) Noble D, Mathur R, Dent T, Meads C, Greenhalgh T. Risk models and scores for type 2 diabetes: systematic review. BMJ 2011; 343:d7163.

(188) Goldenberg RL, Culhane JF, lams JD, Romero R. Epidemiology and causes of preterm birth. Lancet 2008; 371(9606):75-84. 
850 (189) March of Dimes, PMNCH, Save the Children, WHO. Born Too Soon: The global action report on preterm birth. Howson CP, Kinney MV, Lawn JE, editors. 2012. Geneva,

$852 \quad$ World Health Organization.

854 (190) Steegers EA, von Dadelszen P, Duvekot JJ, Pijnenborg R. Pre-eclampsia. Lancet 2010; 376(9741):631-644.

856 (191) Bouwmeester W, Zuithoff NP, Mallett S, Geerlings MI, Vergouwe Y, Steyerberg EW et al. Reporting and methods in clinical prediction research: a systematic review. PLoS Med 2012; 9(5):1-12.

(192) Collins GS, Mallett S, Omar O, Yu LM. Developing risk prediction models for type 2 diabetes: a systematic review of methodology and reporting. BMC Med 2011; 9:103.

(193) Moons KG, de Groot JA, Bouwmeester W, Vergouwe Y, Mallett S, Altman DG et al. Critical appraisal and data extraction for systematic reviews of prediction modelling studies: the CHARMS checklist. PLoS Med 2014; 11(10):e1001744. $62: 451-482$

(195) James BC. Making it easy to do it right. N Engl J Med 2001; 345(13):991-993. 
(196) Reilly BM, Evans AT. Translating clinical research into clinical practice: impact of using prediction rules to make decisions. Ann Intern Med 2006; 144(3):201-209.

(197) Collins GS, Omar O, Shanyinde M, Yu LM. A systematic review finds prediction models for chronic kidney disease were poorly reported and often developed using inappropriate methods. J Clin Epidemiol 2013; 66(3):268-277.

(198) Collins GS, de Groot JA, Dutton S, Omar O, Shanyinde M, Tajar A et al. External validation of multivariable prediction models: a systematic review of methodological conduct and reporting. BMC Med Res Methodol 2014; 14:40.

(199) Mallett S, Royston P, Dutton S, Waters R, Altman DG. Reporting methods in studies developing prognostic models in cancer: a review. BMC Med 2010; 8:20.

(200) Harrell Jr FE. Regression Modeling Strategies. New York: Springer-Verlag; 2001.

(201) Collins GS, Moons KG. Comparing risk prediction models. BMJ 2012; 344:e3186.

(202) Steyerberg EW, Moons KG, van der Windt DA, Hayden JA, Perel P, Schroter S et al. Prognosis Research Strategy (PROGRESS) 3: prognostic model research. PLoS Med 2013; 10(2):e1001381.

(203) Vickers AJ, Cronin AM. Everything you always wanted to know about evaluating prediction models (but were too afraid to ask). Urology 2010; 76(6):1298-1301. 
(204) Collins GS, Reitsma JB, Altman DG, Moons KG. Transparent Reporting of a multivariable prediction model for Individual Prognosis Or Diagnosis: The TRIPOD statement. Ann Intern Med. In press 2015.

(205) Collins G. Opening up multivariable prediction models: consensus-based guidelines for transparent reporting. http://blogs bmj com/bmj/2011/08/03/gary-collinsopening-up-multivariable-prediction-models/ [ 2013 [cited 2013 Aug. 26]; Available from: URL:http://blogs.bmj.com/bmj/2011/08/03/gary-collins-opening-upmultivariable-prediction-models/

(206) Moons KG, Altman DG, Reitsma JB, loannidis JP, Macaskill P, Steyerberg EW et al. Transparent Reporting of a multivariable prediction model for Individual Prognosis Or Diagnosis (TRIPOD): Explanation and Elaboration. Ann Intern Med 2015; 162:W1W73.

(207) Wilson PW, D'Agostino RB, Levy D, Belanger AM, Silbershatz H, Kannel WB. Prediction of coronary heart disease using risk factor categories. Circulation 1998;97(18):183747. 

evaluation

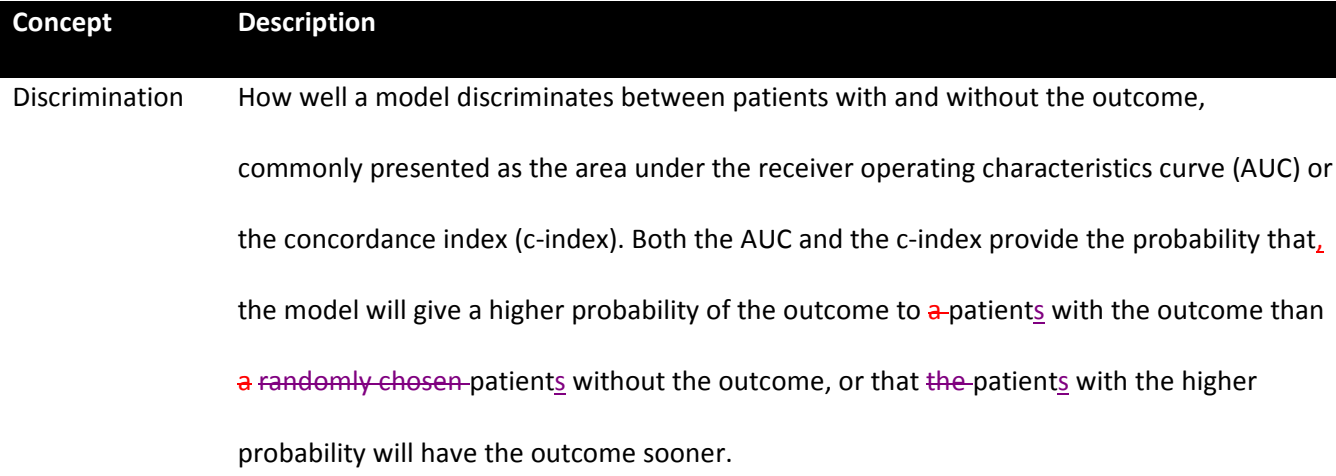

External validity The process of determining external validity, or "generalizability" of the prognostic model 
for populations that are similar to, or related to, the development sample population.

External validation can be performed by the same investigators who developed the model, for example in patients more recently attending for care (temporal) or in another hospital or centre (geographical) but is preferably done by other, fully independent investigators.

Presentation of The format in which the prognostic model is presented so that it can be used to calculate

prognostic risks for individual patients or groups of patients. For a logistic regression model the

model intercept and regression coefficients should be reported, and for a Cox model the baseline survival and regression coefficients. In addition to presenting the full regression formula, other supplementary formats include a nomogram (a graphical presentation of the model with lines for scoring points for each predictor and a line to obtain risk from the sum of points), a score chart, and a table with predictions for certain groups based on combinations of predictor variables.

903

904 Descriptions are adapted from: Steyerberg EW. Clinical Prediction Models. A practical approach to development, validation and updating. New York: Springer; 2009. 
910 Table 1: Overview of available prognostic models

\begin{tabular}{|c|c|c|c|c|c|c|c|}
\hline Outcome & $\begin{array}{l}\text { Number } \\
\text { of models }\end{array}$ & $\begin{array}{l}\text { Internal } \\
\text { validation }\end{array}$ & $\begin{array}{l}\text { External } \\
\text { validation }\end{array}$ & Calibration & Discrimination & $\begin{array}{l}\text { Presentation } \\
\text { Prediction } \\
\text { model }\end{array}$ & $\begin{array}{l}\text { Decision } \\
\text { recommended }\end{array}$ \\
\hline Total & 263 & 57 (21.7\%) & $23(8.7 \%)$ & 46 (17.5\%) & $165(62.7 \%)$ & $164(62.4 \%)$ & 29 (11.0\%) \\
\hline Pre-eclampsia & 69 & $14(20.3 \%)$ & $5(7.2 \%)$ & $8(11.6 \%)$ & $60(87.0 \%)$ & $45(65.2 \%)$ & $9(13.0 \%)$ \\
\hline Eclampsia & 1 & $1(100 \%)$ & 0 & 0 & 1 (100\%) & 0 & 0 \\
\hline $\begin{array}{l}\text { Gestational } \\
\text { hypertension }\end{array}$ & 11 & 0 & 0 & 0 & 7 (63.6\%) & $9 \underline{(81.8 \%)}$ & 0 \\
\hline Preterm delivery & 63 & $15(23.8 \%)$ & 4 (6.3\%) & $7(11.1 \%)$ & $34(54.0 \%)$ & $33(52.4 \%)$ & 7 (11.1\%) \\
\hline Gestational diabetes & 9 & $2(22.2 \%)$ & $1(11.1 \%)$ & $1(11.1 \%)$ & $8(88.9 \%)$ & $3(33.3 \%)$ & $2(22.2 \%)$ \\
\hline $\begin{array}{l}\text { Insulin treatment for } \\
\text { gestational diabetes }\end{array}$ & 1 & 0 & 0 & $1(100 \%)$ & 0 & 0 & 0 \\
\hline $\begin{array}{l}\text { Abnormal glucose } \\
\text { challenge test }\end{array}$ & 1 & 0 & $1(100 \%)$ & 0 & $1(100 \%)$ & $1(100 \%)$ & 0 \\
\hline $\begin{array}{l}\text { Congenital } \\
\text { malformations }\end{array}$ & 3 & 0 & 0 & 0 & $3 \underline{(100 \%)}$ & 0 & 0 \\
\hline $\begin{array}{l}\text { Small for gestational } \\
\text { age neonate }\end{array}$ & 10 & $3 \underline{(30.0 \%)}$ & 0 & $2 \underline{(20.0 \%)}$ & $6 \underline{(60.0 \%)}$ & $5 \underline{(50.0 \%)}$ & 0 \\
\hline $\begin{array}{l}\text { Intra-uterine growth } \\
\text { restriction }\end{array}$ & 4 & $2(50.0 \%)$ & 0 & $1(25.0 \%)$ & $1(25.0 \%)$ & $4(100 \%)$ & $1(25.0 \%)$ \\
\hline Birthweight & 3 & $1(33.3 \%)$ & $2(66.7 \%)$ & 0 & $1(33.3 \%)$ & $3(100 \%)$ & $1(33.3 \%)$ \\
\hline Low birthweight & 1 & $1(100 \%)$ & 0 & $1(100 \%)$ & 0 & $1(100 \%)$ & 0 \\
\hline $\begin{array}{l}\text { Vaginal birth after } \\
\text { caesarean }\end{array}$ & 9 & 4 (44.4\%) & $2(22.2 \%)$ & $3 \underline{(33.3 \%)}$ & $4 \underline{(44.4 \%)}$ & $6(66.7 \%)$ & 0 \\
\hline Induction of labor & 1 & 0 & 0 & 0 & $1(100 \%)$ & $1(100 \%)$ & 0 \\
\hline $\begin{array}{l}\text { Successful induction of } \\
\text { labor }\end{array}$ & 8 & 0 & 0 & 0 & $2 \underline{(25.0 \%)}$ & $4 \underline{(50.0 \%)}$ & 0 \\
\hline Mode of delivery & 22 & $3 \underline{(13.6 \%)}$ & $5 \underline{(22.7 \%)}$ & $10 \underline{(45.5 \%)}$ & $14 \underline{(63.6 \%)}$ & 18 (81.8\%) & $4 \underline{(18.2 \%)}$ \\
\hline Time to delivery & 1 & 0 & 0 & 0 & 0 & 0 & 0 \\
\hline $\begin{array}{l}\text { Successful external } \\
\text { cephalic version }\end{array}$ & 4 & $3(75.0 \%)$ & $3(75.0 \%)$ & $3(75.0 \%)$ & $1(25.0 \%)$ & $4(100 \%)$ & $3(75.0 \%)$ \\
\hline $\begin{array}{l}\text { Vaginal delivery after } \\
\text { external cephalic }\end{array}$ & 1 & $1(100 \%)$ & 0 & 0 & 1 (100\%) & $1(100 \%)$ & 0 \\
\hline
\end{tabular}




\begin{tabular}{|c|c|c|c|c|c|c|c|}
\hline version & & & & & & & \\
\hline $\begin{array}{l}\text { Mode of delivery in } \\
\text { breech presentation }\end{array}$ & 1 & 0 & 0 & 0 & 0 & 0 & 0 \\
\hline $\begin{array}{l}\text { Intra-amniotic infection } \\
\text { and/or inflammation }\end{array}$ & 2 & 0 & 0 & $2 \underline{(100 \%)}$ & $2 \underline{(100 \%)}$ & $2 \underline{(100 \%)}$ & 0 \\
\hline Clinical infection & 1 & $1(100 \%)$ & 0 & 0 & $1(100 \%)$ & $1(100 \%)$ & 0 \\
\hline $\begin{array}{l}\text { Histologic signs of } \\
\text { infection }\end{array}$ & 1 & 0 & 0 & 0 & $1(100 \%)$ & 0 & 0 \\
\hline $\begin{array}{l}\text { Miscarriage or early } \\
\text { fetal loss }\end{array}$ & 2 & 0 & 0 & 0 & $1 \underline{(50.0 \%)}$ & $1 \underline{(50.0 \%)}$ & 0 \\
\hline Stillbirth & 3 & 0 & 0 & 0 & $2 \underline{(66.7 \%)}$ & $2 \underline{(66.7 \%)}$ & 0 \\
\hline $\begin{array}{l}\text { Perinatal mortality or } \\
\text { survival }\end{array}$ & 2 & $1 \underline{(50.0 \%)}$ & 0 & $1 \underline{(50.0 \%)}$ & 0 & $2(100 \%)$ & 0 \\
\hline Poor perinatal outcome & 2 & 0 & 0 & 0 & 0 & $1(50.0 \%)$ & 0 \\
\hline $\begin{array}{l}\text { Hypertensive disorders } \\
\text { (combined) or } \\
\text { placenta-related } \\
\text { complications }\end{array}$ & 3 & 1 (33.3\%) & 0 & 0 & $3 \underline{(100 \%)}$ & $1(33.3 \%)$ & 0 \\
\hline Placenta praevia & 1 & 0 & 0 & 0 & $1(100 \%)$ & 0 & 0 \\
\hline Shoulder dystocia & 3 & $1(33.3 \%)$ & 0 & $1(33.3 \%)$ & $2(66.7 \%)$ & $1(33.3 \%)$ & 0 \\
\hline Birth trauma & 3 & 0 & 0 & 0 & 0 & $3(100 \%)$ & 0 \\
\hline Placental abruption & 4 & 0 & 0 & 0 & $1 \underline{(25.0 \%)}$ & $3 \underline{(75.0 \%)}$ & 0 \\
\hline $\begin{array}{l}\text { Postpartum } \\
\text { hemorrhage }\end{array}$ & 3 & $1 \underline{(33.3 \%)}$ & 0 & $1 \underline{(33.3 \%)}$ & $1 \underline{(33.3 \%)}$ & $2 \underline{(66.7 \%)}$ & 0 \\
\hline Anal sphincter injury & 1 & 0 & 0 & 0 & 0 & $1(100 \%)$ & 0 \\
\hline Thrombosis & 2 & 0 & 0 & 0 & 0 & $2(100 \%)$ & 2 (100\%) \\
\hline $\begin{array}{l}\text { Maternal complications } \\
\text { of attempted VBAC }\end{array}$ & 2 & 0 & 0 & 0 & $2(100 \%)$ & 0 & 0 \\
\hline $\begin{array}{l}\text { Maternal complications } \\
\text { of pre-eclampsia }\end{array}$ & 2 & $2(100 \%)$ & 0 & $2(100 \%)$ & $2(100 \%)$ & $1(50.0 \%)$ & 0 \\
\hline $\begin{array}{l}\text { Combined adverse } \\
\text { pregnancy outcome }\end{array}$ & 1 & 0 & 0 & 0 & 0 & $1(100 \%)$ & 0 \\
\hline Short cervix & 1 & 0 & 0 & $1(100 \%)$ & $1(100 \%)$ & $1(100 \%)$ & 0 \\
\hline Higher CRH levels & 1 & 0 & 0 & $1(100 \%)$ & 0 & $1(100 \%)$ & 0 \\
\hline
\end{tabular}


911 Figure 1: Selection of studies for inclusion in this the systematic review

All studies identified by search on 1 July 2012

$n=10152$

Excluded after screening titles and abstracts

$n=9893$

Not human $(n=95)$

- Not obstetrics ( $n=746$ )

- Comment, letter or editorial $(n=46)$

- Case report $(n=250)$

- Review $(n=1684)$

- Not prognostic or model with $<3$ predictors

$(n=6918)$

- Validation only $(n=34)$

- Protocol $(n=29)$

- Conference abstract $(n=3)$

- Duplicate with other study $(n=3)$

- Other $(n=85)$

Full text assessment

$n=259$

Excluded after screening full text paper

$n=82$

Not obstetrics $(n=10)$

- Not prognostic or model with $<3$ predictors $(n=55)$

- Duplicate with other study $(n=5)$

- Papers in Chinese or Russian $(n=7)$

- Full text not available $(n=5)$

Papers included in systematic review

$n=177$

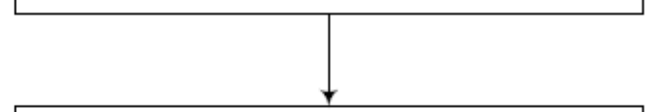

Prediction models included in systematic review

$n=263$ 
913 Figure 2: Cumulative number of published papers describing prognostic models and

914 number of available models and external validation studies

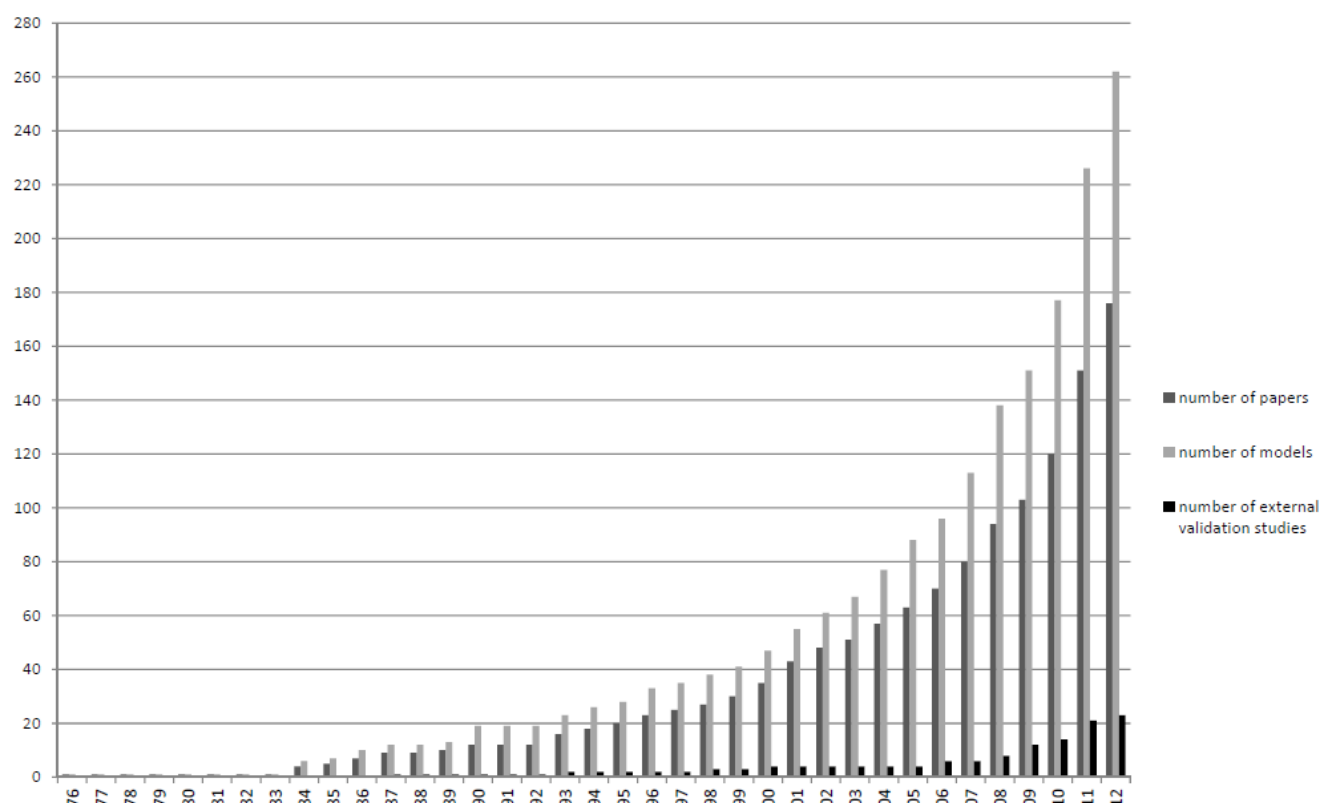

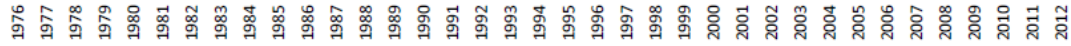

915

916

917

918

919

920

One paper (describing 2 models) was published online in 2012 and in print in 2013. With advancing period, the total number of models increased more than the total number of papers describing these models, so more papers describing more than one model were published. The number of external validation studies does not $\underline{\text { increase as markedly as the number of published prediction models. }}$ 
921 published obstetrical papers per year

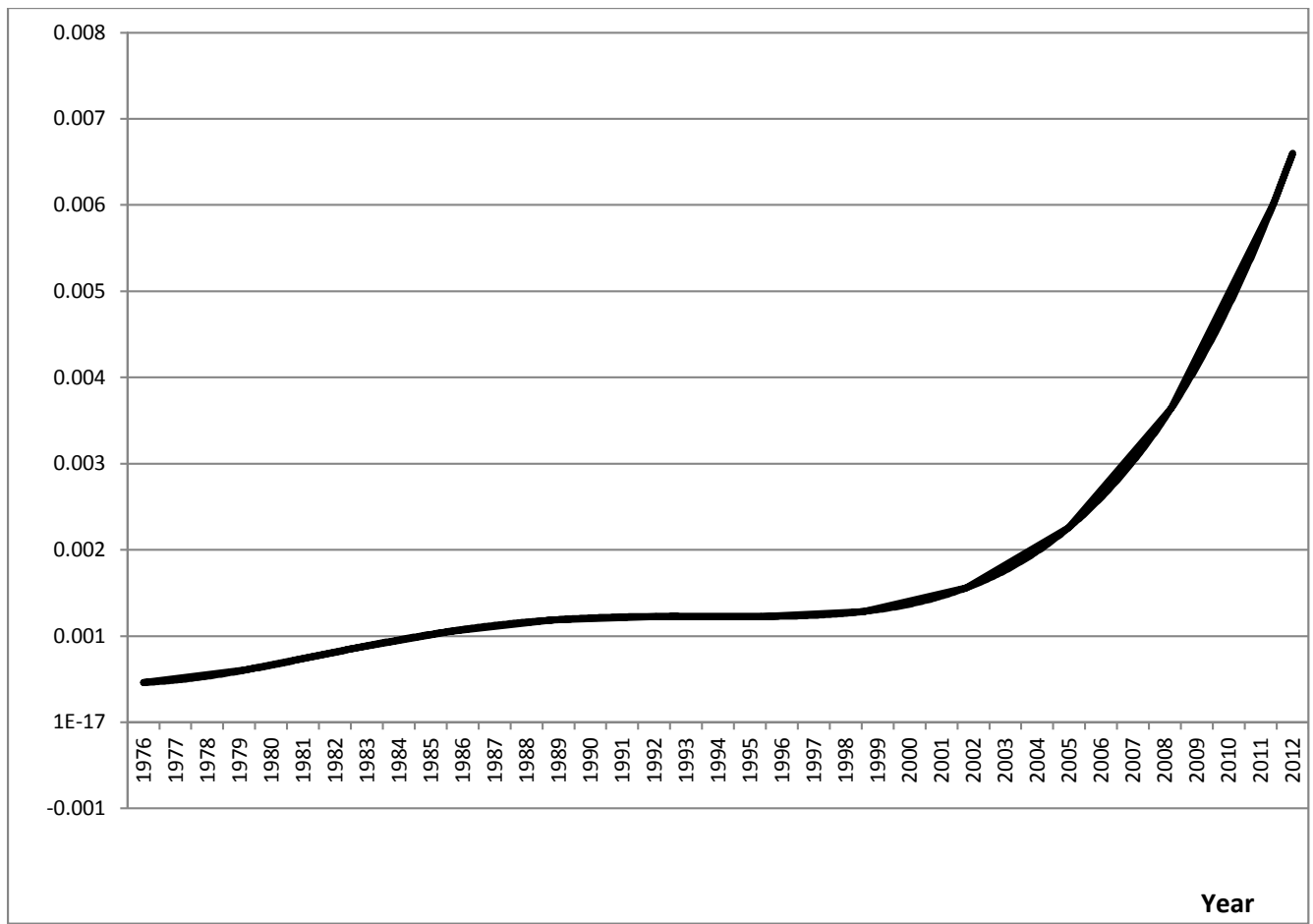




\section{Appendix 1: Search strategy for MEDLINE (through PubMed)}

1. Validat*[tiab] OR Predict*[ti] OR Rule*[tiab]

2. Predict*[tiab] AND (Outcome*[tiab] OR Risk*[tiab] OR Model*[tiab])

3. (History[tiab] OR Variable*[tiab] OR Criteria[tiab] OR Scor*[tiab] OR

Characteristic*[tiab] OR Finding*[tiab] OR Factor*[tiab]) AND (Predict*[tiab] OR Model*[tiab] OR Decision*[tiab] OR Identif*[tiab] OR Prognos*[tiab])

4. Decision*[tiab] AND (Model*[tiab] OR Clinical*[tiab] OR Logistic Model*[tiab])

5. Prognostic[tiab] AND (History[tiab] OR Variable*[tiab] OR Criteria[tiab] OR Scor*[tiab] OR Characteristic*[tiab] OR Finding*[tiab] OR Factor*[tiab] OR Model*[tiab])

6. "risk score"[All fields] OR "prediction model"[All fields] OR "prediction rule"[All fields] OR "risk assessment"[All fields] OR "algorithm"[All fields]

7. \# 1 OR \#2 OR \#3 OR \#4 OR \#5 OR \#6

8. $\operatorname{pregnan*[tiab]~OR~obstetric*[tiab]~OR~woman[tiab]~OR~women[tiab]~}$ VBAC[tiab] OR anal sphincter rupture[tiab] OR post partum haemorrhage[tiab] OR vacuum extraction[tiab] OR forceps extraction [tiab] OR caesarean [tiab] OR casarean [tiab] OR caesarian [tiab] OR cesarian [tiab] OR shoulder dystocia[tiab] OR manual placenta removal[tiab] OR gestational diabetes[tiab] OR placenta praevia[tiab] OR abruption [tiab] OR cervical incompetence[tiab] OR cervical length [tiab] OR growth restrict* OR external cephalic version[tiab] OR breech OR rupture of membranes[tiab] OR PROM[tiab] OR PPROM [tiab] OR preeclampsia[tiab] OR preeclampsia [tiab] OR pregnancy induced hypertension[tiab] OR HELLP[tiab] OR vaginal deliver* [tiab] OR preterm deliver* [tiab] OR preterm labour [tiab] OR preterm labor [tiab] OR preterm birth [tiab]

9. \#7 AND \#8

\#9 NOT (Animals[MeSH] NOT Humans[MeSH) 